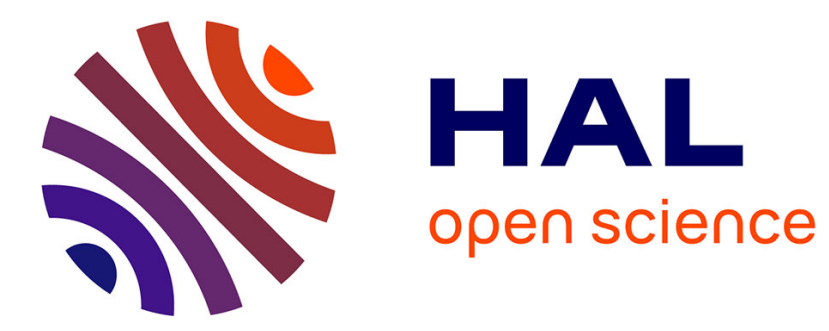

\title{
Towards an experimental approach for measuring the removal of urban air pollutants by green roofs
}

\author{
Yara Arbid, Claire Richard, Mohamad Sleiman
}

\section{To cite this version:}

Yara Arbid, Claire Richard, Mohamad Sleiman. Towards an experimental approach for measuring the removal of urban air pollutants by green roofs. Building and Environment, 2021, 205, pp.108286. 10.1016/j.buildenv.2021.108286 . hal-03329684

\section{HAL Id: hal-03329684 \\ https://hal.science/hal-03329684}

Submitted on 8 Sep 2021

HAL is a multi-disciplinary open access archive for the deposit and dissemination of scientific research documents, whether they are published or not. The documents may come from teaching and research institutions in France or abroad, or from public or private research centers.
L'archive ouverte pluridisciplinaire HAL, est destinée au dépôt et à la diffusion de documents scientifiques de niveau recherche, publiés ou non, émanant des établissements d'enseignement et de recherche français ou étrangers, des laboratoires publics ou privés. 

green roofs

5 University Clermont Auvergne, CNRS, Clermont Auvergne INP, Institut de Chimie de Clermont-Ferrand

$6 \quad$ F-63000 Clermont-Ferrand, France

$7 \quad$ Yara.arbid@etu.uca.fr

8 Claire.richard@uca.fr

$9 \quad$ Mohamad.sleiman@sigma-clermont.fr

$10 *$ Corresponding author: Mohamad Sleiman - University Clermont Auvergne, CNRS, Clermont Auvergne

11 INP, Institut de Chimie de Clermont-Ferrand F63000 Clermont-Ferrand, France; orcid.org/0000-0002-

12 2273-1053; Email: Mohamad.sleiman@sigma-clermont.fr 
Green roofs are a promising approach to mitigate air pollution in urban environments, but limited experimental data is yet available. In this study, we developed a laboratory-scale setup to measure the removal nitrogen dioxide $\left(\mathrm{NO}_{2}\right)$ and ozone $\left(\mathrm{O}_{3}\right)$ using a variety of common green roof species.

17 Experiments were conducted on detached leaves and whole plants using two chambers (0.6 L and $12 \mathrm{~L})$,

18 visible lighting, $\mathrm{NOx} / \mathrm{O}_{3}$ sources and online analyzers. Three species were the best performant (Thymus

19 vulgaris, Sedum sexangulare and Heuchera Americana L.) with deposition velocities $\left(v_{d}\right)$ ranging from

201.6 to $4.82 \mathrm{~m} / \mathrm{h}$ for $\mathrm{NO}_{2}$, and 1.7 to $5.56 \mathrm{~m} / \mathrm{h}$ for $\mathrm{O}_{3}$. In both cases, thyme was the most effective plant

21 likely due to its higher stomatal area and the reactivity of its volatile metabolites with $\mathrm{O}_{3}$ leading to

22 several oxidized by-products. Furthermore, $\mathrm{NO}_{2}$ uptake was found to be enhanced by surface water 23 released by leaf transpiration leading to the production of nitrous acid (HONO). Similar values of $\left(v_{d}\right)$ 24 were observed $(3.84-4.65 \mathrm{~m} / \mathrm{h})$ when whole thyme plant was used. The soil was also found to be 25 competitive in removing $\mathrm{O}_{3}$ but less performant in capturing $\mathrm{NO}_{2}$. Using a dry deposition model, we 26 estimated that the three plant species can uptake up to $9 \mathrm{~kg} / \mathrm{ha} / \mathrm{year}$ of $\mathrm{NO}_{2}$ and $13.6 \mathrm{~kg} / \mathrm{ha} / \mathrm{year}$, which fall 27 in agreement with previously reported modeling data. Our experimental approach can be a rapid tool for 28 screening the depollution performances of green roof species enabling an effective prioritization for 29 deployment in urban environments.

30 Keywords: Green roofs, air pollution, $\mathrm{NOx}, \mathrm{O}_{3}$.

\section{INTRODUCTION}

Outdoor air pollution causes up to 10 million deaths annually, and around $90 \%$ of the world 33 population live in urban environments where air pollution exceeds the World Health Organization (WHO)

34 limits [1]. Air pollution mitigation strategies such as source reduction (electrical vehicles [2], fuel and 35 traffic regulations [3], renewable energy resources [4], etc.), and depollution technologies have been 36 increasingly adopted in the recent years. Among depollution methods, the use of highly reflective 
37 photocatalytic roofs and walls [5] have been shown to be effective in reducing the urban heat island effect, 38 and in the removal of Volatile Organic Compounds (VOCs) and Nitrogen Oxides (NOx) [6,7]. However, 39 photocatalytic oxidation process can lead to the formation of toxic intermediates and the VOC removal 40 performance can decrease over time [8]. Another promising alternative is the use of natural walls and 41 roofs such as vertical greening systems or green roofs which can be a replacement to conventional roofs 42 especially in crowded urbanized areas [9]. Green roofs have been receiving attention recently as effective 43 nature-based solution to eco-environmental problems arising from climate change and rapid urbanization 44 [10]. They can retain storm water via absorption into the substrate $[11,12]$, reduce the building energy 45 demand by improving the thermal insulation [13], lower noise pollution [14], in addition to improving the 46 roof aesthetic values.

Plants used in such green roofs are able to mitigate air pollution [15] by absorbing the pollutants 48 through their stomata via dry deposition on the surfaces of leaves [16]. Urban trees and shrubs are known 49 to remove efficiently air pollutants [17]. Reactive pollutants $\left(\mathrm{O}_{3}, \mathrm{NOx}, \mathrm{SO}_{2}\right)$ can be removed by 50 absorption via stomata or by surface uptake via potential chemical reactions with volatile metabolites such 51 as terpenes. On the other hand, the formed particulate matter (PM) can be removed via deposition on the 52 leaf surface. The performance depends on various factors such as the proximity of the vegetation to the 53 road and its height [18]. Although trees are a very effective strategy in controlling pollution, planting trees 54 in crowded cities with high percentages of impervious areas is challenging. Thus, in metropolitan cities, 55 green roofs can be an alternative solution to make use of rooftops [19]. Several modelling studies showed 56 that green roofs can be efficient in removing various prevalent air pollutants. According to Yang et al., $5722.8 \mathrm{~kg} / \mathrm{ha} /$ year of $\mathrm{NO}_{2}$ and around $44 \mathrm{~kg} / \mathrm{ha} /$ year of $\mathrm{O}_{3}$ can be eliminated using green roofs [16]. Grass 58 was found effective in removing $\mathrm{O}_{3}(5.2 \mathrm{~kg} / \mathrm{ha} /$ year $)$ whereas, shrubs have the potential to eliminate 18 $59 \mathrm{~kg} / \mathrm{ha} /$ year of $\mathrm{PM}_{10}$ [20]. Speak et.al [21] showed that sedum, a widely used plant species on extensive 60 green roofs, could remove $4.2 \mathrm{~kg} / \mathrm{ha} /$ year of $\mathrm{PM}_{10}$. However, most aforementioned studies were based 
61 solely on modelling using estimated deposition velocities $\left(v_{d}\right)$ which can vary significantly depending on

62 the plant species, seasonality, climate, etc.

To the best of our knowledge, the air depollution performance of green roofs species has been very little investigated, and only limited recent data exist on their efficiency in the laboratory and in the

65 field [22,23]. Performance-based laboratory screening measurements -in combination with field 66 campaigns- are thus needed to improve the precision of models and to provide a valuable tool for

67 implementing the best performant species as a function of target pollutants. In this study, we developed an experimental setup to measure the $\mathrm{NOx} / \mathrm{O}_{3}$ uptakes of 13 plants commonly used on green roofs. After initial screening, 3 species were selected (Sedum sexangulare, Thymus vulgaris, and Heuchera micrantha palace purple). The removal rates of these plants were investigated using detached leaves as well as full

71 size plants. This work aimed to guide in the choice of plants to be used on green roofs according to the

72 need of targeting a specific pollutant in an urbanized area, and to get insight into the mechanisms taking 73 place.

Imidacloprid (IMD) was purchased from Sigma Aldrich, Switzerland (Pestanal ${ }^{\mathrm{TM}}$, analytical standard, $77 \geq 98.0 \%$ purity HPLC area \%). Sodium carbonate anhydrous was purchased from Fluka, Germany 78 ( $\geq 99.5 \%$ purity ACS). Both were used without further purification. Water was produced using a reverse 79 osmosis RIOS 5 and Synergy (Millipore) device (resistivity $18 \mathrm{M} \Omega \mathrm{cm}, \mathrm{DOC}<0.1 \mathrm{mg} \mathrm{L}^{-1}$ ). Acetonitrile 80 (ACN) was purchased from Carlo Erba Reagents (HPLC Plus Gradient grade-ACS-Reag.

81 Process of plant selection: Green roofs vary from intensive to extensive roofs differing in the maintenance 82 needs, substrate depth, plants implemented, etc. Contrarily to intensive ones where shrubs or even trees 83 may be implemented, extensive green roofs use shallow root plants and thus are more commonly used due 84 to their low maintenance needs and lightweight. Hence, in this study, we solely focused on extensive 85 green roof species which are drought tolerant such as grasses, perennials, and succulents. Based on 
86 literature review, and after careful consideration of weather conditions in central France, 13 species were 87 selected for screening: Achillée millefeuille paprika, Achillea umbellate à feuillage gris, Alchemille jaune,

88 Aster des alpes rose,Heuchera americana L., Joubarbe calcareum, Joubarbe rubin, Thymus nummularius,

89 Sedum floriferum jaune, Sedum reflexum jaune, Sedum sexangulare, Sedum spurium, and Thymus

90 vulgaris. After pre-screening, three species were chosen to further investigate their performance for the

91 removal of $\mathrm{O}_{3}$ and $\mathrm{NO}_{2}$ : Sedum sexangulare, Thymus vulgaris, Heuchera americana $L$.

92 Conditions for plant storage and care: Plants were stored in an indoor greenhouse exposed to outdoor 93 sunlight through a large window and were watered every two days. Temperature was between $20-25^{0} \mathrm{C}$ 94 in the greenhouse during storage and around $23^{\circ} \pm 2 \mathrm{C}$ when used in the laboratory. Relative humidity (RH) was ranged between $30-55 \%$.

96 Sedum sexangulare, Thymus vulgaris, and Heuchera micrantha palace purple were purchased from a 97 plant nursery (Botanic $®$, Beaumont, France) and watered every two days. These species are used on green 98 roofs and different studies report their performance towards different air pollutants [24-26].

99 Sedum sexangulare (sedum): Sedum species are considered as appropriate plants to be applied on 100 extensive green roofs. They are drought tolerant and can survive in harsh climate conditions. In the 101 literature, Sedum sexangulare showed a good performance under severe climate conditions and that it is 102 suitable to be implemented in a Mediterranean climate [24].

103 Thymus vulgaris (thyme): Thyme is an odorous perennial plant used on green roofs. It emits different 104 VOCs (Fig.SI-1.) which can react with air pollutants [25].

105 Heuchera Americana L. (heuchera): Heuchera species are used in vertical greenery systems and green 106 roofs because their colorful glossy leaves give them important aesthetics values. Heuchera retains 107 different elements and particulate matter (PM) due to its hairy undersides [26]. 
108 Plants were stored in an indoor greenhouse with direct solar light. They were either used directly as a full109 size plant (pot size: 9-15 cm) or their leaves cut using scissors into pieces of $0.9-1.2 \mathrm{~g}$ prior to the 110 experiment.

111 To avoid changes induced by diurnal cycles, all experiments using plants were performed during the day 112 from 10 am to $3 \mathrm{pm}$. The planting soil was a universal soil with a water retention capacity of $75 \%$, $113 \mathrm{pH}=6.5$, and $\mathrm{N}, \mathrm{P}, \mathrm{K}$ values of $5.5,2.5$, and 1.5 for $2 \mathrm{~kg} / \mathrm{m}^{3}$ respectively.
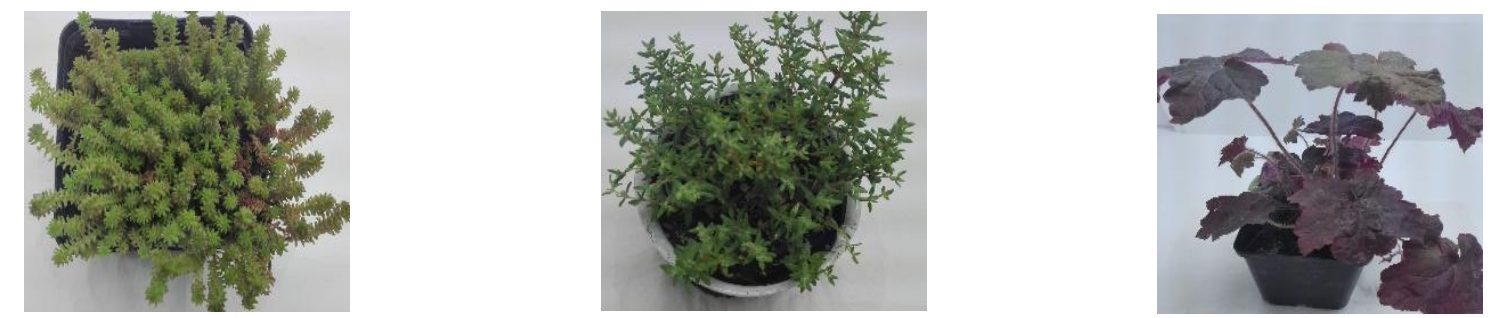

Fig.1. Pictures of the 3 studied plants: Sedum sexangulare, Thymus vulgaris, and Heuchera Americana L. (left to right).

\subsection{Experimental setup}

A new experimental setup was designed to measure the uptakes of leaves and the full-size plant

119 under irradiation with $\mathrm{NOx}$ and $\mathrm{O}_{3}$ configurations. 


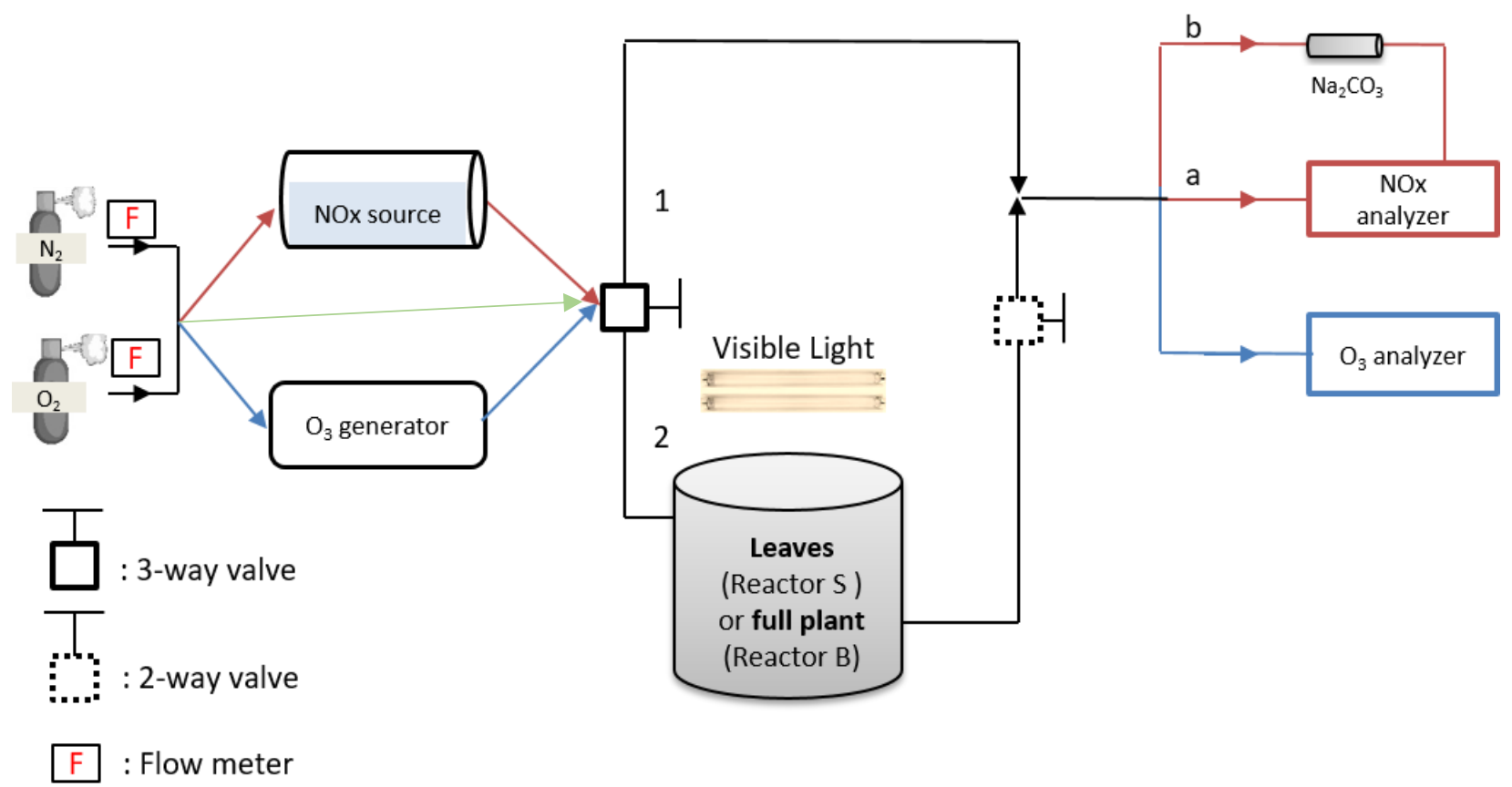

Fig.2. Experimental setup used for measuring the uptake of $\mathrm{NO}_{2}$ (red) and $\mathrm{O}_{3}$ (blue).

$120 \underline{\mathrm{NOx} / \mathrm{O}_{3}}$ setup The setup includes:

121 1. Two flow meters (Brooks 4800 series/ 50-500 ml/min) to regulate the flow of $\mathrm{O}_{2}$ and $\mathrm{N}_{2}$ 122 simultaneously mimicking the ratio of these gases in ambient air.

123 2. An NOx source via a $200 \mathrm{ml}$ solution of IMD $\left(10^{-5} \mathrm{M}\right)$ producing $40-50 \mathrm{ppbv}$ of $\mathrm{NO}_{2}$ and $0.1-0.5$ 124 ppbv of NO contained in a cylindrical Pyrex glass flow-reactor $(0.65 \mathrm{~L}$, length $27 \mathrm{~cm}$ and internal diameter $5.7 \mathrm{~cm}$ ). This was based on our previous study showing that irradiating a solution of IMD with a polychromatic light $\left(\lambda_{\max }=365 \mathrm{~nm}\right)$ leads to the production of $\mathrm{NOx}\left(\mathrm{NO}+\mathrm{NO}_{2}\right)$ with $\mathrm{NO}_{2}$ being the major product [27].

A UVP ozone generator equipped with a UV pen-ray lamp that uses the photochemical reaction of $\mathrm{O}_{2}$ under UVC $(185 \mathrm{~nm})$ to produce the continuous flow of $\mathrm{O}_{3}$.

3. Two air-tight stainless-steel reactors (see Fig.SI-2.) that are cylindrical with a Pyrex glass top window for irradiation. A small one (Reactor S- $0.6 \mathrm{~L}$ ) for leaves and a big reactor (Reactor B- 12 L) for the full-size plant. 
4. $2 \times 55 \mathrm{~W}$ Starlite tubes $(\lambda=400-800 \mathrm{~nm})$ that were placed at a distance of $\approx 30 \mathrm{~cm}$ above the reactors for irradiation. Absolute Irradiance at this distance was 6-7 $\mu \mathrm{W} / \mathrm{cm}^{2} / \mathrm{nm} @ 610 \mathrm{~nm}$. This lamp is commonly used for growing plants indoors where it covers the light range needed for photosynthesis (see spectrum Fig.SI-3.).

5. A NOx Thermo scientific 42i model-NO $\mathrm{NO}_{2}$ NOx analyzer (chemiluminescence analyzer). To measure the nitrous acid (HONO) and estimate its contribution to the $\mathrm{NO}_{2}$ measured levels, a $\mathrm{Na}_{2} \mathrm{CO}_{3}$-impregnated quartz filter was installed upstream of the NOx monitor, to trap HONO. Its concentration was then calculated by measuring the difference between measured $\mathrm{NO}_{2}$ values with and without the HONO scrubber.

An O342e ozone analyzer $\mathrm{O}_{3}$ (Environnement S.A). Both analyzers were online real-time analyzers with a $10 \mathrm{~s}$ temporal resolution.

The tubes used were PTFE (Teflon) to minimize secondary reactions, the fitting and valves were stainless steel from Swagelok (Lyon-France), and the temperature was regulated to $23{ }^{\circ} \mathrm{C}$ by an air conditioner.

\subsection{Calculation of deposition velocities and plant uptake coefficients}

For the plants tested in this study, transient deposition velocities $\left(v_{d}\right)$ for $\mathrm{NO}_{2}$ and $\mathrm{O}_{3}$ were calculated, similar to Poppendieck et al. [28] and Abbass et al.[29], based on a mass balance that is shown in equation (1):

$$
\frac{d C_{\text {out }}}{d t}=\lambda\left(C_{\text {in }}-C_{\text {out }}\right)-v_{d(p)} C_{\text {out }} \frac{A_{(p)}}{V}-v_{d(c)} C_{o u t} \frac{A_{(c)}}{V}
$$

151 Where $\frac{d C_{\text {out }}}{d t}$ represents the change in the outlet $\mathrm{O}_{3}$ or $\mathrm{NO}_{2}$ concentration $\left(\mathrm{ppb} \mathrm{h}^{-1}\right), \mathrm{C}_{\text {in }}$ and $\mathrm{C}_{\text {out }}$

152 are the outlet concentration of $\mathrm{NO}_{2}$ or $\mathrm{O}_{3}$, in the inlet and the outlet of the exposure chamber 153 (ppbv), respectively, $\lambda$ is the air exchange rate for the chamber $\left(\mathrm{h}^{-1}\right), v_{d(p)}$ and $v_{d(c)}$ are the 154 deposition velocities for a plant and chamber $(\mathrm{m} / \mathrm{h})$, respectively, $A_{(p)}$ and $A_{(c)}$ are the exposed 
155 area of the plant and chamber walls $\left(\mathrm{m}^{2}\right)$, respectively. Eq. (1) was solved for the transient deposition 156 velocity shown in equation (2):

$$
v_{d(p)}^{t}=\frac{V}{A_{(p)}} \frac{1}{C_{\text {out }}^{t}}\left[\lambda\left(C_{\text {in }}^{t}-C_{\text {out }}^{t}\right)-v_{d(c)} C_{o u t} \frac{A_{(c)}}{V}-\frac{C_{\text {out }}^{t}-C_{\text {out }}^{t+1}}{\Delta t}\right]
$$

158 Where $v_{d(p)}^{t}$ is the time varying deposition velocity for a plant, $\mathrm{t}$ and $\mathrm{t}$ indicate consecutive data 159 points (h), $\mathrm{V}$ is the volume of the test chamber. The deposition velocity associated with chamber 160 walls $v_{d(c)}$ was observed to be negligible for all experiments. To facilitate comparison across 161 plants, the near steady-state deposition velocity was calculated when the rate of change in exit 162 concentration was less than 2 ppb over 15 min. The uptake coefficients $U_{p}^{t}$ were then calculated 163 by multiplying the deposition velocity $v_{d(p)}^{t}$ by the inlet concentration of $\mathrm{NO}_{2}$ or $\mathrm{O}_{3}\left(C_{\text {in }}^{t}\right)$ after 164 its conversion from ppbv to $\mu \mathrm{g} / \mathrm{m}^{3}$ (eq. 3).

$$
U_{p}^{t}=v_{d(p)}^{t}\left(C_{i n}^{t}\right)
$$

\subsection{Analytical methods}

167 VOC analysis. The composition of VOC produced by the three plant species was determined using 168 headspace gas chromatography coupled with mass spectrometry detection (HS-GC/MS; Shimadzu HS-20 169 coupled with QP2010SE). $1 \mathrm{~g}$ of leaves from each species was transferred into a $20 \mathrm{~mL}$ headspace glass 170 vial and incubated for $10 \mathrm{~min}$ at $80{ }^{\circ} \mathrm{C}$. The analytical column (Mega 5-MS $30 \mathrm{~m} \times 0.25 \mathrm{~mm}$ ) was 171 operated initially at $60^{\circ} \mathrm{C}$ for $1 \mathrm{~min}$, followed by an $8^{\circ} \mathrm{C} \mathrm{min}{ }^{-1}$ ramp to reach $240^{\circ} \mathrm{C}$ and held for $4 \mathrm{~min}$.

172 The mass spectrometer source was heated to $200^{\circ} \mathrm{C}$, and signals were detected between mass to charge 173 ratios $(\mathrm{m} / \mathrm{z})$ of 50 and 350 . Identification of the major constituents was carried out using the NIST 17 174 database and when necessary, using authentic standards. 
$A T D-G C-M S$. After the ozonation of thyme leaves, the reactor gas phase was sampled for 3 min at a

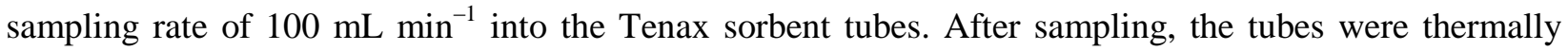
desorbed using TurboMatrix thermal desorption unit (ATD 150, Perkin Elmer) equipped with a cold trap (Carbotrap 300) and coupled to an Agilent 6890 gas chromatograph and an Agilent 5973 mass spectrometry detector. The separation of desorbed volatiles was carried out using a HP-5 $\mu$ s column ( $25 \mathrm{~m}$ $\times 0.25 \mathrm{~mm} \times 0.25 \mu \mathrm{m}$ ) operated initially at $50{ }^{\circ} \mathrm{C}$ for $1 \mathrm{~min}$, followed by a $10^{\circ} \mathrm{C} / \mathrm{min}$ ramp to reach $230^{\circ} \mathrm{C}$. Mass spectra were scanned between $\mathrm{m} / \mathrm{z} 35$ and m/z 350 with the source temperature set at $20^{\circ} \mathrm{C}$.

HPLC-DAD. HPLC analyses were performed using a NEXERA XR HPLCDAD apparatus. Separation was conducted using a phenomenex reversed phase $\mathrm{C} 18$ column $(100 \mathrm{~mm} \times 2.1 \mathrm{~mm}, 2.6 \mu \mathrm{m}$ particle size $)$ and a binary solvent system composed of $10 \%$ acetonitrile and $90 \%$ water at a flow of $0.2 \mathrm{~mL} / \mathrm{min}$. Analysis time was 10 minutes. HPLC analyses allowed the monitoring of thymol disappearance as well as its absorption spectrum.

Scanning electron microscopy (SEM). The structure of thyme cuticular surfaces before and after ozonation were characterized using scanning electron microscope. Leaves were mounted on aluminum stubs using double-sided adhesive tape and sputter-coated with 10-15 nm gold-palladium (20 s, $25 \mathrm{~mA}$, partial argon pressure 60 mTorr, Denton Desk V. The samples were investigated with a field-emission scanning electron microscope (SH $4000 \mathrm{M}$ ) using a $20 \mathrm{kV}$ acceleration voltage and a $10 \mathrm{~mm}$ working distance. Pictures were taken from adaxial and abaxial leaf surfaces.

\section{RESULTS AND DISCUSSION}

3.1. Depollution capacity of detached leaves

3.1.1. $\mathrm{NO}_{2}$ uptake

A maximum of $1 \mathrm{~g}$ of leaves was irradiated in the reactor for $1 \mathrm{hr}$ while being ventilated with pure synthetic air at a flow rate of $0.8 \mathrm{~L} / \mathrm{min}$ (green line in Fig. 2) under visible light allowing the plant to adapt to the conditions given before measuring the uptake. During this period, $\mathrm{NO}_{2}$ generated by IMD was 
199 directly monitored and its average concentration was found to be relatively stable around $50 \pm 2$ ppbv. 200 Following the $1 \mathrm{~h}$ pre-conditioning of the plant, $\mathrm{NO}_{2}$ gas flow was introduced into the reactor containing 201 the detached leaves and the $\mathrm{NO}_{2}$ concentration was monitored initially every 10 seconds and then 202 regularly until reaching a steady-state to calculate the $\mathrm{NO}_{2}$ uptake. In control experiment, $\mathrm{NO}_{2}$ flow was 203 passed through empty chamber (no leaves) and its concentration showed negligible drop suggesting a 204 negligible background removal of $\mathrm{NO}_{2}$ due to chamber walls (See Fig. 3). In the presence of detached 205 leaves of green roof species, the chamber exit concentration of $\mathrm{NO}_{2}$ concentration increases quickly in the 206 first minute as the chamber is filled with constant level $\mathrm{NO}_{2}$ followed by a slower and progressive 207 increases until approaching a steady-state after $1 \mathrm{~h}$ of exposure. At the end of the experiment, thyme 208 showed the highest $\mathrm{NO}_{2}$ uptake with a reduction of about $9 \mathrm{ppbv}$ in $\mathrm{NO}_{2}$ concentration followed by sedum 209 and heuchera with a reduction of about 5-6 ppbv. The near steady-state deposition velocities for the three 210 plants were calculated by averaging the last $15 \mathrm{~min}$ of the exposure. 


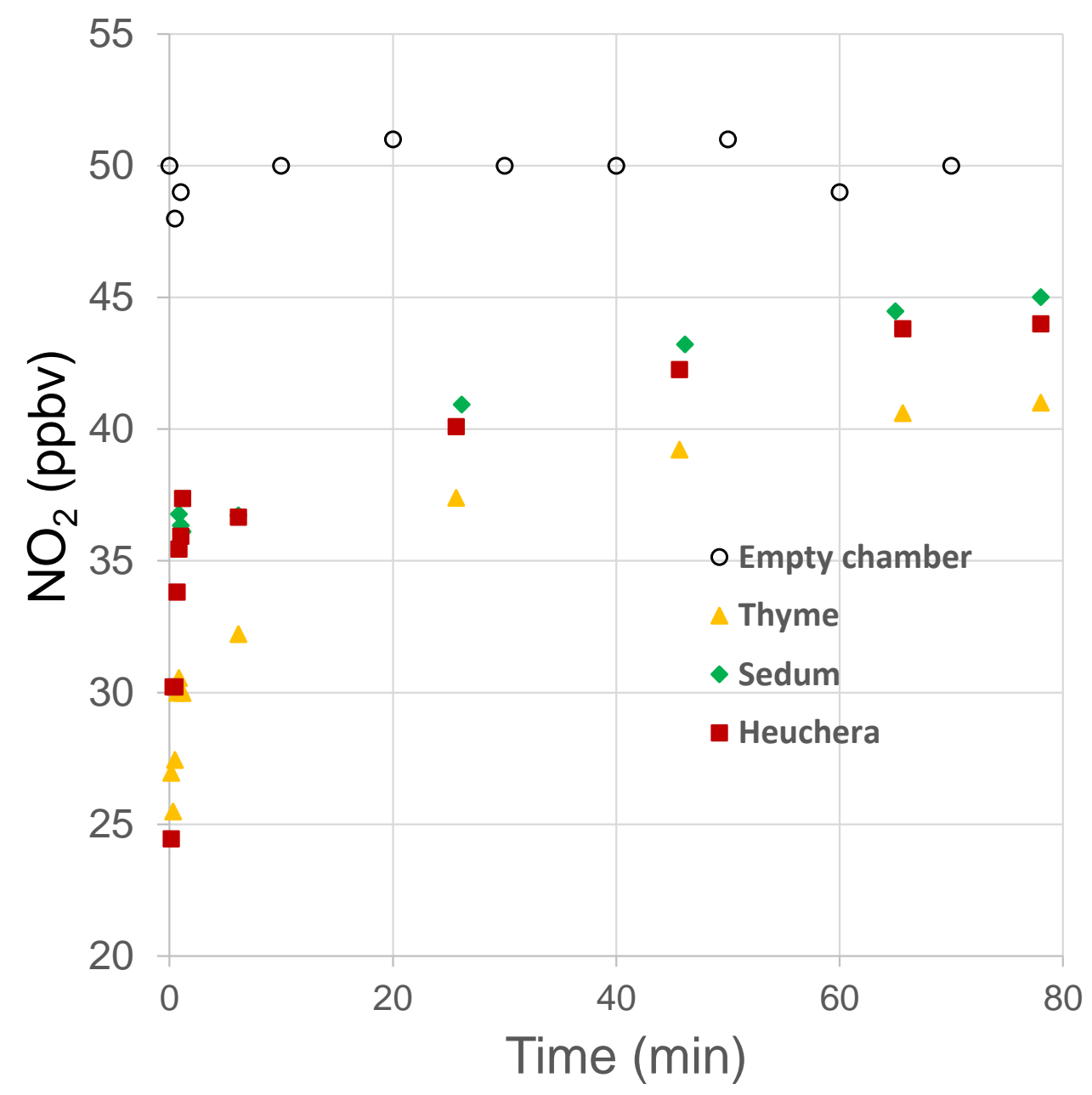

Fig.3. Empty chamber and outlet $\mathrm{NO}_{2}$ concentration for sedum, thyme, and heuchera.

212 Table 1 shows the near steady-state $\mathrm{NO}_{2}$ deposition velocities and corresponding uptake coefficients 213 for the three plant species tested. While Heuchera seems to perform as good as sedum according to Fig. 3, 214 the exposed surface of its leaves was twice higher than that for Sedum and Thyme due to its large leaves. 215 Yang et al [16] estimated the removal capacity of 71 green roofs using a big leaf dry deposition model and 216 reported an average uptake coefficient of $260 \mu \mathrm{g} / \mathrm{m}^{2} / \mathrm{h}$ for $\mathrm{NO}_{2}$ which is comparable to the values reported 217 in this study. In addition, the calculated $v_{d(p)}^{t}(1.70-5.56)$ fall also within the range of $v_{d}$ in their model $218(0.36-21.6 \mathrm{~m} / \mathrm{h})$. Our values are also in agreement with those reported by Currie and Bass [20] who used 219 the UFORE model (urban forest effects model) and grass as a proxy unit for green roofs and reported an $220 \mathrm{NO}_{2}$ uptake of $300 \mu \mathrm{g} / \mathrm{m}^{2} / \mathrm{h}$. 
221 Table.1. Near steady-state $\mathrm{NO}_{2}$ deposition velocities and plant uptake coefficients

\begin{tabular}{|l|l|l|}
\hline Plant & $\boldsymbol{v}_{\boldsymbol{d}(\boldsymbol{p})}^{\boldsymbol{t}}(\mathrm{m} / \mathrm{h})$ & $\boldsymbol{U}_{\boldsymbol{p}}^{\boldsymbol{t}}\left(\mu \mathrm{g} / \mathrm{m}^{2} / \mathrm{h}\right)$ \\
\hline Sedum & 2.99 & 282 \\
\hline Thyme & 5.56 & 523 \\
\hline Heuchera & 1.70 & 160 \\
\hline
\end{tabular}

To better understand the uptake mechanisms and the difference between studied species, several experimental factors such as the stomata, water and chemical reactions were investigated.

\section{- $\quad$ Effect of stomata}

Leaf stomates are very important organs on the leaf surface as they control exchange of plants with released [30].
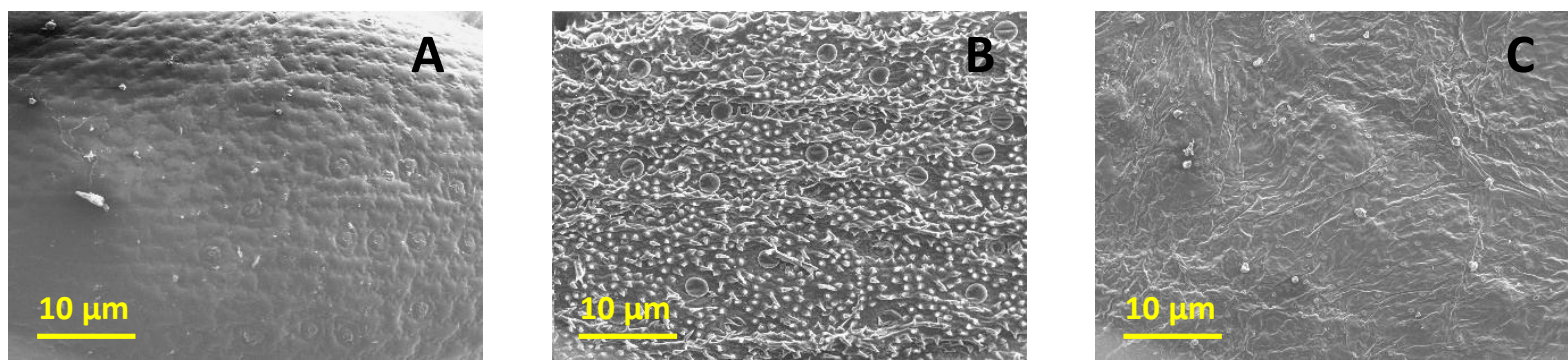

Fig.4. SEM Images of the three studied plants: sedum (A), thyme (B), and heuchera (C).

Using SEM, we observed the stomates on each leaf and estimated the stomatal density and average stomatal areas by taking into consideration abaxial and adaxial sides. Highest stomata density was seen 
238 A fraction of the consumption of $\mathrm{NO}_{2}$ could be due to reactions with VOCs emitted by the plants. In 239 general, $\mathrm{NO}_{2}$ has a low reactivity towards VOCs. However, $\mathrm{NOx}$ might generate $\mathrm{O}_{3}$ by photolysis under 240 UV. As UV was not present, this pathway should be negligible. An alternative possibility is the decay of $241 \mathrm{NO}_{2}$ through reaction with water leading to the formation of nitrous acid or HONO (process 1).

$$
2 \mathrm{NO}_{2}+\mathrm{H}_{2} \mathrm{O} \rightarrow \mathrm{HONO}+\mathrm{HNO}_{3}
$$

(process 1)

243 Such reaction is possible in the case of sedum particularly as it is an evergreen plant with moist leaves 244 and transpiration can occur. In our experiments, sedum might release moisture after being irradiated and 245 its water might react with $\mathrm{NO}_{2}$ to yield $\mathrm{HONO}$. We checked this hypothesis by performing experiments 246 aiming to monitor the formation of $\mathrm{HONO}$. This was done by including $\mathrm{Na}_{2} \mathrm{CO}_{3}$ trap to sample $\mathrm{HONO}$ as 247 described in the experimental section. In the same conditions as before, $1 \mathrm{~g}$ of leaves was irradiated under 248 visible light for $1 \mathrm{~h}$ and the $\mathrm{NO}_{2}$ uptake was monitored using sodium carbonate as a trap. The difference in 249 the $\mathrm{NO}_{2}$ uptake in the presence and absence of the trap reveals the uptake due to the reaction between $\mathrm{NO}_{2}$ 250 and water. Comparing the $\mathrm{NO}_{2}$ values with and without the trap, we conclude that $55 \%$ of the uptake 251 capacity was due to the reaction as shown in process 1. In the case of other species, no significant HONO 252 production was observed, confirming that $\mathrm{NO}_{2}$ uptake in the case of sedum is enhanced by surface water 253 and its reaction with $\mathrm{NO}_{2}$. This finding highlights the importance of chemical reaction in addition to 254 stomatal uptake in the overall performance of plant species and could have implication on the 255 photochemistry of air pollutants since HONO can undergo direct photolysis to produce hydroxyl radicals $256\left(\mathrm{OH}^{\bullet}\right)$

Fig.5. illustrates the time evolution of the outlet concentration of $\mathrm{O}_{3}$ in the case of an empty chamber 259 and in presence of the three studied plants. The same steps were followed as the ones in part 2.1 using 

same plants, irradiation system, and duration (1 hour of pre-conditioning in the chamber). As for the 261 experiment with $\mathrm{NO}_{2}$, thyme showed the highest $\mathrm{O}_{3}$ uptake with a reduction of about 10 ppbv followed by 262 sedum and heuchera with a reduction of about 6-7 ppbv. Table.2 shows the near steady-state $\mathrm{O}_{3}$ 263 deposition velocities and plant uptake coefficients for the three studied plants calculated by averaging the 264 last $20 \mathrm{~min}$ of the exposure.

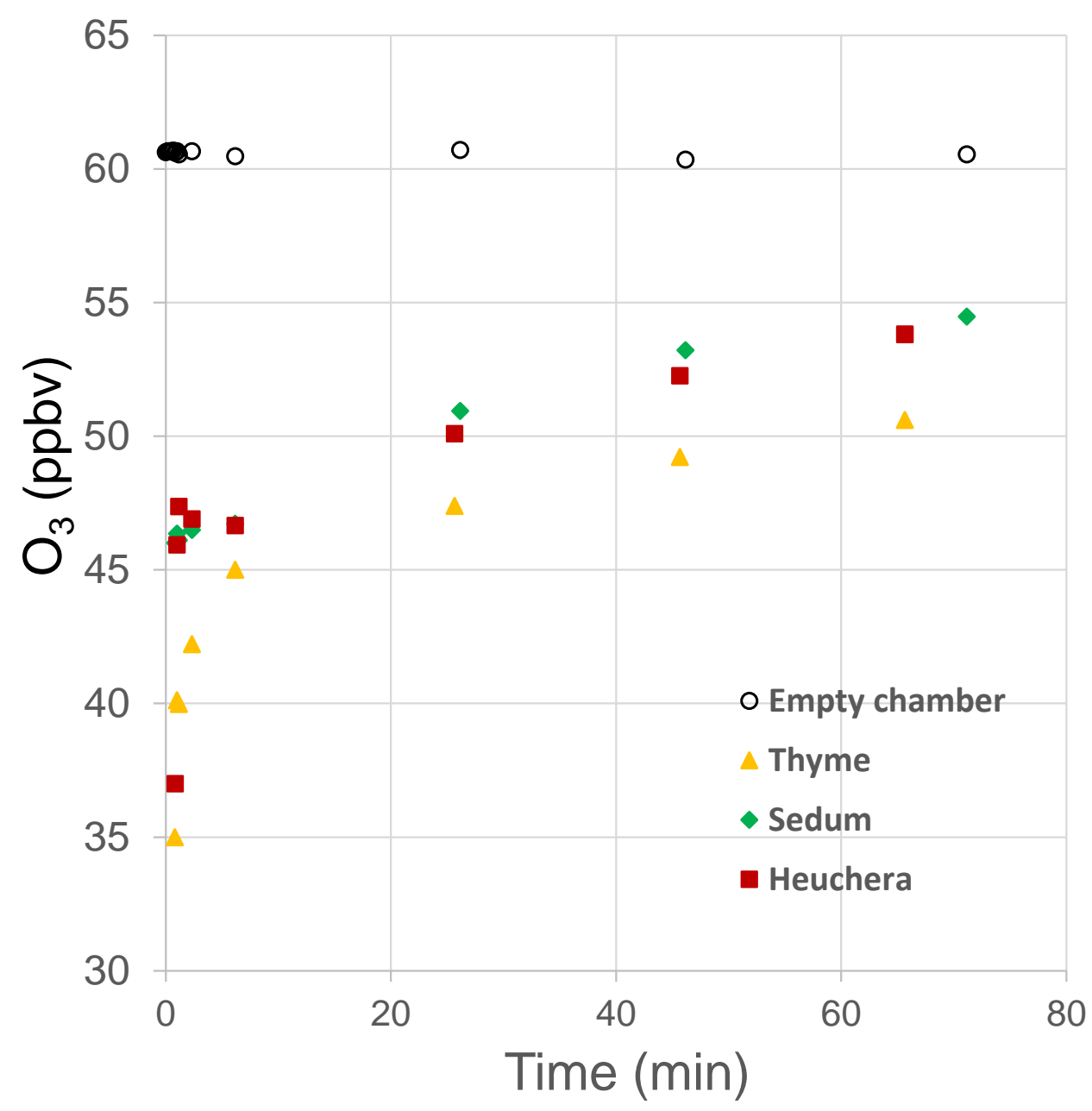

Fig.5. Empty chamber and outlet $\mathrm{O}_{3}$ concentration for sedum, thyme, and heuchera.

267 Table.2. Near steady-state $\mathrm{O}_{3}$ deposition velocities and plant uptake coefficients.

\begin{tabular}{|l|l|l|}
\hline Plant & $\boldsymbol{v}_{\boldsymbol{d}(\boldsymbol{p})}^{\boldsymbol{t}}(\mathrm{m} / \mathrm{h})$ & $\boldsymbol{U}_{\boldsymbol{p}}^{\boldsymbol{t}}\left(\mu \mathrm{g} / \mathrm{m}^{2} / \mathrm{h}\right)$ \\
\hline
\end{tabular}




\begin{tabular}{|l|l|l|}
\hline Sedum & 2.69 & 317 \\
\hline Thyme & 4.82 & 569 \\
\hline Heuchera & 1.60 & 189 \\
\hline Yang et.al [10] & 1.8 & $100-6500$ \\
\hline Curie et. Bass [11] & 0.18 & - \\
\hline
\end{tabular}

The calculated values in our study are in agreement with those reported by Yang et al. [16] whereas the study of Curie et Bass [20] showed lower values compared to those found here.

271 While the higher stomatal area can be responsible for the better performance of thyme in removing $\mathrm{O}_{3}$,

$272 \mathrm{O}_{3}$ can potentially react with plant volatile metabolites particularly in the case of thyme which is known to 273 release several terpenes in addition to thymol. For these reasons, thyme was selected as the main species 274 to study in the following experiments. For a simpler approach, experiments were undertaken with one of 275 the major emitted VOC, thymol (a phenolic derivative), first in solution to examine the feasibility of 276 thymol degradation by $\mathrm{O}_{3}$ and to facilitate the identification of by-products. $\mathrm{O}_{3}$ reactions in solutions can 277 be easier to perform and could provide a first indication of possible heterogeneous reactions between 278 thymol and $\mathrm{O}_{3}$ on leaves. Water can also be present on leaf surface and could participate in the reaction 279 mechanisms. Following this feasibility test, additional experiments on thyme leaves were carried out to 280 mimic realistic conditions and to investigate the heterogeneous reactivity of thyme volatiles with $\mathrm{O}_{3}$.

281 Reaction of thymol with ozone in solution. We prepared a $20 \mathrm{ml}$ solution of thymol $\left(2 \times 10^{-4} \mathrm{M}\right)$ in $\mathrm{ACN}$ 282 and $\mathrm{O}_{3}$ at a concentration of 4 ppm was bubbled into it for almost $6 \mathrm{~h}$. Results were monitored by HPLC283 DAD analysis that showed that $50 \%$ of thymol was degraded. The percentage of degradation is related to 284 ozone and thymol concentrations. According to a study on the catalytic ozonation of thymol, the 285 simplified proposed degradation mechanism is the following: the para and ortho positions of the 286 hydroxyl on thymol are attacked by $\mathrm{O}_{3}$ and hydroxyl radical. This leads to diols with a backbone of 287 cymene (Fig.6.). Several reactions then can take place prompting mineralization [25]. 


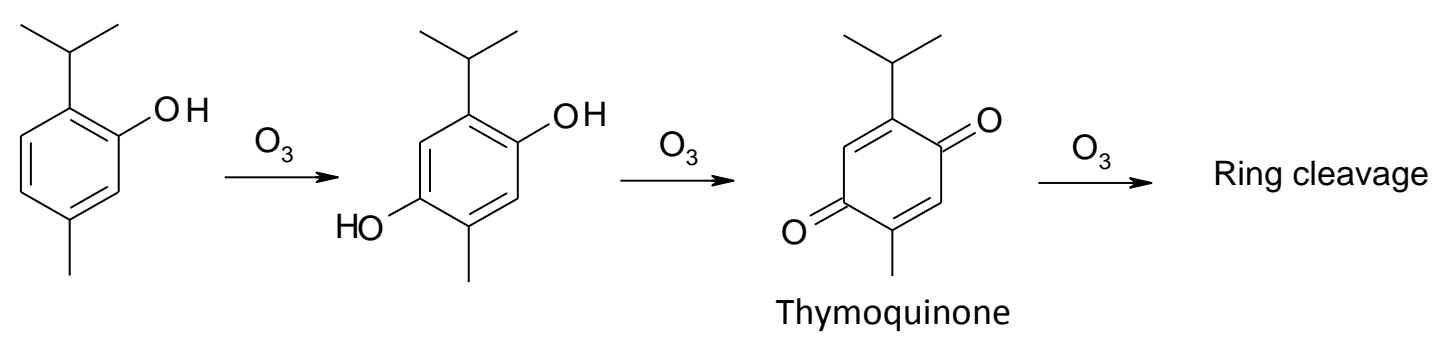

Fig.6. Thymol degradation pathway via the reaction with $\mathrm{O}_{3}$.

The GC-MS analysis of an experiment conducted on thymol and $\mathrm{O}_{3}$ revealed the production of

290 Thymoquinone which corroborates the proposed mechanism.

291 Reaction of thyme VOCs with ozone. Two samples of detached thyme leaves (2 g) were introduced into 292 Pyrex flow-reactors, under irradiation with visible light. To monitor the effect of $\mathrm{O}_{3}$, the first sample (S1) 293 was not exposed to $\mathrm{O}_{3}$ while the second (S2) was exposed to $\mathrm{O}_{3}(153 \mathrm{ppbv})$. In both cases, the production 294 of VOC was monitored via sampling on sorbent tubes followed by ATD-GC-MS analysis.

295 Table.3. shows the four major terpenes emitted in addition to thymol. After $1 \mathrm{~h}$ of ozonation, their 296 levels decreased drastically as expected since terpenes are known to undergo oxidation by $\mathrm{O}_{3}$. This was 297 associated with the identification of various oxidation products such as linalool-oxide, keto298 limononaldehyde and thymoquinone. This finding confirms the role that plays thyme VOC metabolites in 299 the observed good performance for the removal of $\mathrm{O}_{3}$. However, while the uptake of ozone can be 300 enhanced by the emission of terpenes, one should consider the consequences of $\mathrm{O}_{3}$ reactions with terpenes 301 since it can lead to the formation of secondary organic aerosols (SOA) [31]. Unfortunately, this was not 302 confirmed here but future experiments are needed to measure the possible emission of ultrafine particles 303 due to reaction of $\mathrm{O}_{3}$ with thyme volatiles, and to estimate its impact on air pollution. 


\begin{tabular}{|c|c|c|c|c|c|}
\hline \multirow{2}{*}{ Sample } & \multicolumn{5}{|c|}{ VOC collected mass (ng) } \\
\cline { 2 - 6 } & Cymene & Limonene & Thymol & Eucalyptol & Linalool \\
\hline S1 (no O3) & 12.6 & 8.5 & 22.5 & 13.2 & 31.3 \\
\hline S2 (with O & & & & 0.3 & 1.6 \\
\hline
\end{tabular}

\subsection{Depollution capacity of thyme full-size plant}

\subsection{1. $\mathrm{NO}_{2} / \mathrm{O}_{3}$ uptakes}

These following experiments were conducted using a small thyme plant (with an estimated total leaf area of $500 \mathrm{~cm}^{2}$ ) which was pre-conditioned in the big reactor $(12 \mathrm{~L})$ with $1 \mathrm{~h}$ visible light irradiation while soil was fully covered during experiments to ensure the least interference possible. After $1 \mathrm{~h}$ of exposure to $\mathrm{NO}_{2}(50 \mathrm{ppbv})$ the $\mathrm{NO}_{2}$ concentration dropped to reach a near-steady state around 10 ppbv. Using eq.(1) and (2) we calculated a $v_{d(p)}^{t}$ of $3.84 \mathrm{~m} / \mathrm{h}$. In the case of $\mathrm{O}_{3}$, same conditions were used as with detached leaves with the exception of $\mathrm{O}_{3}$ inlet concentration which was increased to $110 \pm 3$ ppbv to reduce measurement uncertainty. Under these conditions, $\mathrm{O}_{3}$ concentration dropped by around $91 \mathrm{ppbv}$ to reach 19 ppbv after $1 \mathrm{~h}$ of exposure (Fig. SI-4). Assuming a near steady-state condition we obtained a $v_{d(p)}^{t}$ of $4.65 \mathrm{~m} / \mathrm{h}$. These values are comparable with those obtained using detached leaves particularly when considering the uncertainty in the estimation of total leaf area, presence of soil, emission of volatile metabolites and the measurement uncertainty. It is noteworthy that a small production of NO was observed when thyme plant was irradiated which was not detected with detached leaves.NO is a key signaling molecule in plant physiology. However, its production in photosynthetic organisms remains partially unresolved. The best characterized NO production route involves the reduction of nitrite $\left(\mathrm{NO}_{2}^{-}\right)$ to NO via different non-enzymatic or enzymatic mechanisms. To better characterize the role of soil in the production of NO and the uptake of pollutants, additional experiments using soil only were carried out.

\section{- Effect of soil on NOx production and uptake and of $\mathrm{O}_{3}$ uptake}



production were studied. In these experiments the same soil used for thyme was studied here.

327 NOx production. After $1 \mathrm{~h}$ of visible light irradiation, a mixture of $\mathrm{N}_{2}$ and $\mathrm{O}_{2}$ (pure synthetic air) was 328 passed through the reactor containing the soil to monitor the $\mathrm{NO} / \mathrm{NO}_{2}$ production. Studied soil was either 329 wet or dry, but the steps were the same in both cases. Only NO was produced at a level of $\approx 20 \mathrm{ppbv}$ in the 330 case of dry soil, and $\approx 10 \mathrm{ppbv}$ in that of wet soil (Fig.SI-5.). Irrigation, N-fertilizers, and bacteria are 331 known to be responsible for $\mathrm{NO}_{2}$ production [32]. In our experiments, the adsorbed $\mathrm{NO}_{2}$ is probably 332 undergoing reactions producing $\mathrm{NO}_{(\mathrm{g})}$ in case of both dry and wet soils; or reacting with water producing 333 ions e.g. $\mathrm{NO}_{2}^{-}$and $\mathrm{NO}_{3}{ }^{-}$(case of wet soil). $\mathrm{NO}_{2} / \mathrm{O}_{3}$ uptake. The same experimental steps were followed as in section 3.2. In the case of $\mathrm{O}_{3}$ 335 (see Fig. SI-4), the reduction in concentration $(\Delta)$ for exposed soil ranged between 85 (dry) and 88 (wet) $336 \mathrm{ppbv}$ which is very close to that observed with thyme (91 ppbv). This suggests that soil can also be as 337 effective in removing $\mathrm{O}_{3}$ and could contribute to increase the overall performance of green roofs. On the 338 other hand, soil contributed to the removal of $15 \mathrm{ppbv}$ (wet) to $35 \mathrm{ppbv}$ (dry) of $\mathrm{NO}_{2}$ as compared with 339 about $40 \mathrm{ppbv}$ for thyme (Fig. SI-6) indicating that the thyme plant is more effective in removing $\mathrm{NO}_{2}$. 340 The higher $\mathrm{NO}_{2}$ uptake by dry soil is likely associated with the higher surface area available for adsorption 341 as compared with wet soil which can be partially saturated with water.

\section{CONCLUSION}

Natural air pollution mitigation approaches are needed to help improve air quality especially in urbanized areas. One promising recommended approach is the use of green roofs. In this study, we developed a new $\mathrm{NO}_{2} / \mathrm{O}_{3}$ bench-scale experimental system to measure the depollution performance of 346 different green roofs species.

After the screening of several species, 3 species were found to be the most efficient for the 
349 between being aesthetically pleasant, drought tolerant, climate resilient, and exhibiting good uptakes. $\mathrm{NO}_{2}$ 350 uptake coefficients ranged from 160 to $523 \mu \mathrm{g} / \mathrm{m}^{2} / \mathrm{h}$ while that of $\mathrm{O}_{3}$ varied between 189 and $569 \mu \mathrm{g} / \mathrm{m}^{2} / \mathrm{h}$.

351 These findings are in accordance with previously reported data using the big-leaf dry deposition models.

352 Nevertheless, values were relatively higher in our experiments possibly due to other mechanisms than dry 353 deposition (adsorption) such as the reactions between the VOCs and $\mathrm{O}_{3}$ especially in the case of thyme, 354 and between $\mathrm{NO}_{2}$ and water in the case of the evergreen plant: sedum -which are not considered yet in 355 models. If we apply our experimental results using the existing model [16] by taking the average 356 deposition velocity in our experiments $\left(0.095 \mathrm{~m} / \mathrm{h}\right.$ for $\mathrm{NO}_{2}$ and $\left.0.084 \mathrm{~m} / \mathrm{h} \mathrm{for} \mathrm{O}_{3}\right)$, the total uptake by the 3 357 species (sedum, thyme, and heuchera) could reach $9 \mathrm{~kg} / \mathrm{ha} / \mathrm{year}$ of $\mathrm{NO}_{2}$ and around $13.6 \mathrm{~kg} / \mathrm{ha} / \mathrm{year}$ of $\mathrm{O}_{3}$. 358 Assuming that Paris has around 76 ha of green roofs and walls (2016) [33], and if the three species 359 investigated in this study were to be used, one can estimate that $683 \mathrm{~kg} / \mathrm{year}$ of $\mathrm{NO}_{2}$ and $1037 \mathrm{~kg} / \mathrm{year}$ of $360 \mathrm{O}_{3}$ can be mitigated.

While our study focused only on the uptake of two air pollutants, additional research should be 362 carried to measure the performance of green roof species towards $\mathrm{PM}_{2.5}$ and to investigate the potential 363 formation of SOA. In addition, our experimental design does not consider some important variables such 364 as the effects of humidity, lighting spectrum/intensity changes, nor the diurnal and seasonal cycles of the 365 plant. In addition, field evaluation of laboratory results should be carried in order to better understand the 366 effects of seasonality and weather conditions on the depollution performance of green roofs.

\section{ASSOCIATED CONTENT}

Supporting information (e-component) 6 figures

The Volatile Organic Compounds emitted by thyme obtained by headspace-GC-MS. The small and big reactors containing the detached leaves and the full-size plant/soil. The light spectrum of the

371 lamps used in our experiments for irradiation. $\mathrm{O}_{3}$ uptakes by Thyme and soil (wet and dry) after 
372 irradiation. NO production by the soil (wet and dry) after being irradiated by visible light for $1 \mathrm{~h} . \mathrm{NO}_{2}$

373 uptakes by the soil (wet and dry) after $1 \mathrm{~h}$ of visible light irradiation.

\section{ACKNOWLEDGEMENTS}

Y. ARBID thanks Peng CHENG for his technical assistance, Adelina DAVID and Mr. Yann analysis.

\section{FUNDING SOURCES}

This work was supported by the University of Clermont Auvergne and the French Ministry of

Higher Education and Research.

\section{REFERENCES}

[1] World Health Organization, Air pollution, (2019). https://www.who.int/health-topics/air-pollution.

[2] J. Zhao, X. Xi, Q. Na, S. Wang, S.N. Kadry, P.M. Kumar, The technological innovation of hybrid and plug-in electric vehicles for environment carbon pollution control, Environ. Impact Assess. Rev. 86 (2021). https://doi.org/10.1016/j.eiar.2020.106506.

[3] R. Zalakeviciute, Y. Rybarczyk, J. López-Villada, M.V. Diaz Suarez, Quantifying decade-long effects of fuel and traffic regulations on urban ambient PM2.5 pollution in a mid-size South American city, Atmos. Pollut. Res. 9 (2018) 66-75. https://doi.org/10.1016/j.apr.2017.07.001.

[4] M. Granovskii, I. Dincer, M.A. Rosen, Air pollution reduction via use of green energy sources for electricity and hydrogen production, Atmos. Environ. 41 (2007) 1777-1783. https://doi.org/10.1016/j.atmosenv.2006.10.023.

[5] X. Tang, O. Rosseler, S. Chen, S. Houzé de l'Aulnoit, M.J. Lussier, J. Zhang, G. Ban-Weiss, H. Gilbert, R. Levinson, H. Destaillats, Self-cleaning and de-pollution efficacies of photocatalytic architectural membranes, Appl. Catal. B Environ. 281 (2021) 119260. https://doi.org/10.1016/j.apcatb.2020.119260.

[6] X. Tang, L. Ughetta, S.K. Shannon, S. Houzé de l'Aulnoit, S. Chen, R.A.T. Gould, M.L. Russell, J. Zhang, G. Ban-Weiss, R.L.A. Everman, F.W. Klink, R. Levinson, H. Destaillats, De-pollution efficacy of photocatalytic roofing granules, Build. Environ. 160 (2019) 106058. https://doi.org/https://doi.org/10.1016/j.buildenv.2019.03.056.

[7] J. Chen, C. Poon, Photocatalytic construction and building materials: From fundamentals to applications, Build. Environ. 44 (2009) 1899-1906. 
https://doi.org/https://doi.org/10.1016/j.buildenv.2009.01.002.

403

404

405

406

407

408

409

410

411

412

413

414

415

416

417

418

419

420

421

422

423

424

425

426

427

428

429

430

431

432

433

434

435

436

437

438

439

[8] M. Krichevskaya, S. Preis, A. Moiseev, N. Pronina, J. Deubener, Gas-phase photocatalytic oxidation of refractory VOCs mixtures: Through the net of process limitations, Catal. Today. 280 (2017) 93-98. https://doi.org/10.1016/j.cattod.2016.03.041.

[9] A. Palla, I. Gnecco, L.G. Lanza, Unsaturated 2D modelling of subsurface water flow in the coarsegrained porous matrix of a green roof, J. Hydrol. 379 (2009) 193-204. https://doi.org/10.1016/j.jhydrol.2009.10.008.

[10] H. Liu, F. Kong, H. Yin, A. Middel, X. Zheng, J. Huang, H. Xu, D. Wang, Z. Wen, Impacts of green roofs on water, temperature, and air quality: A bibliometric review, Build. Environ. 196 (2021) 107794. https://doi.org/10.1016/j.buildenv.2021.107794.

[11] J. Mentens, D. Raes, M. Hermy, Green roofs as a tool for solving the rainwater runoff problem in the urbanized 21st century?, Landsc. Urban Plan. 77 (2006) 217-226. https://doi.org/10.1016/j.landurbplan.2005.02.010.

[12] L.M. Cook, T.A. Larsen, Towards a performance-based approach for multifunctional green roofs: An interdisciplinary review, Build. Environ. 188 (2021) 107489. https://doi.org/10.1016/j.buildenv.2020.107489.

[13] Y. He, H. Yu, A. Ozaki, N. Dong, S. Zheng, Long-term thermal performance evaluation of green roof system based on two new indexes: A case study in Shanghai area, Build. Environ. 120 (2017) 13-28. https://doi.org/10.1016/j.buildenv.2017.04.001.

[14] T. Van Renterghem, D. Botteldooren, Numerical evaluation of sound propagating over green roofs, J. Sound Vib. 317 (2008) 781-799. https://doi.org/10.1016/j.jsv.2008.03.025.

[15] D.B. Rowe, Green roofs as a means of pollution abatement, Environ. Pollut. 159 (2011) 21002110. https://doi.org/10.1016/j.envpol.2010.10.029.

[16] J. Yang, Q. Yu, P. Gong, Quantifying air pollution removal by green roofs in Chicago, Atmos. Environ. 42 (2008) 7266-7273. https://doi.org/10.1016/j.atmosenv.2008.07.003.

[17] D.J. Nowak, D.E. Crane, J.C. Stevens, Air pollution removal by urban trees and shrubs in the United States, Urban For. Urban Green. 4 (2006) 115-123. https://doi.org/10.1016/j.ufug.2006.01.007.

[18] V. Etyemezian, S. Ahonen, D. Nikolic, J. Gillies, H. Kuhns, D. Gillette, J. Veranth, Deposition and removal of fugitive dust in the arid southwestern united states: Measurements and model results, J. Air Waste Manag. Assoc. 54 (2004) 1099-1111. https://doi.org/10.1080/10473289.2004.10470977.

[19] N.W. Lepp, Planting Green Roofs and Living Walls, J. Environ. Qual. 37 (2008) 2408-2408. https://doi.org/10.2134/jeq2008.0016br.

[20] B.A. Currie, B. Bass, Estimates of air pollution mitigation with green plants and green roofs using the UFORE model, Urban Ecosyst. 11 (2008) 409-422. https://doi.org/10.1007/s11252-008-0054$\mathrm{y}$.

[21] A.F. Speak, J.J. Rothwell, S.J. Lindley, C.L. Smith, Urban particulate pollution reduction by four 
species of green roof vegetation in a UK city, Atmos. Environ. 61 (2012) 283-293. https://doi.org/10.1016/j.atmosenv.2012.07.043.

[22] O.A. Abbass, D.J. Sailor, E.T. Gall, Ozone removal efficiency and surface analysis of green and white roof HVAC filters, Build. Environ. 136 (2018) 118-127. https://doi.org/10.1016/j.buildenv.2018.03.042.

[23] P. Ramasubramanian, I. Luhung, S.B.Y. Lim, S.C. Schuster, O. Starry, E.T. Gall, Impact of green and white roofs on air handler filters and indoor ventilation air, Build. Environ. 197 (2021) 107860. https://doi.org/https://doi.org/10.1016/j.buildenv.2021.107860.

[24] G. Pérez, C. Chocarro, A. Juárez, J. Coma, Evaluation of the development of five Sedum species on extensive green roofs in a continental Mediterranean climate, Urban For. Urban Green. 48 (2020) 126566. https://doi.org/10.1016/j.ufug.2019.126566.

[25] L. Wang, A. Liu, Z. Zhang, B. Zhao, Y. Xia, Y. Tan, Catalytic ozonation of thymol in reverse osmosis concentrate with core/shell Fe3O4@SiO2@Yb2O3 catalyst: Parameter optimization and degradation pathway, Chinese J. Chem. Eng. 25 (2017) 665-670. https://doi.org/10.1016/j.cjche.2016.10.017.

[26] U. Weerakkody, J.W. Dover, P. Mitchell, K. Reiling, Quantification of the traffic-generated particulate matter capture by plant species in a living wall and evaluation of the important leaf characteristics, Sci. Total Environ. 635 (2018) 1012-1024. https://doi.org/10.1016/j.scitotenv.2018.04.106.

[27] D. Palma, Y. Arbid, M. Sleiman, P. De Sainte-Claire, C. Richard, New Route to Toxic Nitro and Nitroso Products upon Irradiation of Micropollutant Mixtures Containing Imidacloprid: Role of NOx and Effect of Natural Organic Matter, Environ. Sci. Technol. 54 (2020) 3325-3333. https://doi.org/10.1021/acs.est.9b07304.

[28] D. Poppendieck, H. Hubbard, M. Ward, C. Weschler, R.L. Corsi, Ozone reactions with indoor materials during building disinfection, Atmos. Environ. 41 (2007) 3166-3176. https://doi.org/10.1016/J.atmosenv.2006.06.060.

[29] O.A. Abbass, D.J. Sailor, E.T. Gall, Effectiveness of indoor plants for passive removal of indoor ozone, Build. Environ. 119 (2017) 62-70. https://doi.org/10.1016/j.buildenv.2017.04.007.

[30] B. Grant, I. Vatnick, Environmental correlates of leaf stomata density, Teaching Issues and Experiments in Ecology, TIEE Volume 1 (2004) 1-6. Ecological Society of America. (www.tiee.ecoed.net).

[31] X. Chen, P.K. Hopke, W.P.L. Carter, Secondary Organic Aerosol from Ozonolysis of Biogenic Volatile Organic Compounds: Chamber Studies of Particle and Reactive Oxygen Species Formation, Environ. Sci. Technol. 45 (2011) 276-282. https://doi.org/10.1021/es102166c.

[32] C.H. Jaeger, R.K. Monson, M.C. Fisk, S.K. Schmidt, Seasonal partitioning of nitrogen by plants and soil microorganisms in an alpine ecosystem, Ecology. 80 (1999) 1883-1891. https://doi.org/10.1890/0012-9658(1999)080[1883:SPONBP]2.0.CO;2.

[33] M.A. Kleiber. A Paris, quel est l'impact réel de la végétalisation des toits. https://www.lejdd.fr/JDD-Paris/a-paris-quel-est-limpact-reel-de-la-vegetalisation-des-toits3798761. 